INTERNATIONAL JOURNAL OF RESEARCHES IN BIOSCIENCES, AGRICULTURE AND TECHNOLOGY

(C) VISHWASHANTI MULTIPURPOSE SOCIETY (Global Peace Multipurpose Society) R. No. MH-659/13(N) www.vmsindia.org

\title{
SEASONAL DISTRIBUTION AND POPULATION DYNAMICS OF AQUATIC INSECTS IN ASHTI LAKE, DIST. WARDHA (M.S)
}

\author{
U. W. Fule' 1 S. S. Nimgare, P. M. Telkhade 2 and S. B. Zade ${ }^{3}$ \\ ${ }^{1}$ Dept. of Zoology, H.R. Arts and Science College Ashti, Dist : Wardha \\ ${ }^{2}$ Arts and Science College, Tukum, Dist: Chandrapur \\ ${ }^{3}$ Department of Zoology RTM Nagpur University Nagpur. \\ patankar.kargi@gmail.com
}

\begin{abstract}
:
Ashti lake of District, Wardha is a nutrient rich reservoir was investigated to analyse the seasonal abundance and population variation of aquatic insects from January 2010 to December 2012. The study depicts that the insect population was higher during the months of June, September and october. The maximum in June, when an average of seven insect were discovered in one $\mathrm{ml}$. of sample. The population density was found to be lower in the remaining months, being lowest in February, March, when on an average only one insect / ml of sample were encountered.
\end{abstract}

keyword : Aquatic insects, Population dynamics, Distribution.

\section{Introduction :}

Insects are dominant macroinvertebrates present in all aquatic environments. Their remarkable adaptability to varied conditions has enabled them to survive and grow in all seasons. Ashti lake of Wardha District is an ideal harbour for the growth and survival of many insect as water of the reservoir is highly productive and support a large number of aquatic plants which provide food, shelter and protection of the aquatic insects (Bath, 1996).This paper describes the seasonal distribution and population abundance of aquatic insectsencountered at Ashti Lake of District Wardha.

\section{Material and Methods :}

For the study of aquatic insects, surface water sampleswere collected periodically from January 2010 to December 2012.in a wide mouthed plastic bottle $(250 \mathrm{ml})$ tied to a planktonic net. Approximately, 50 liters of water was allowed to pass through the net to collect one sample. Benthic insects were collected by using 'Ekman's dredge. Insects were also collected from under the stones, gravels and vegetation by hand picking. The collected insect were preserved in 5\% formalin solution and brought to the laboratory for macro and microscopic study.

The insect fauna was identified using standard references (Ward and Whipple, 1959, Mallan by, 1963; Pennak, 1978 ; Tonapi, 1980 ; Willians and Feltmate, 1992)

\section{Results and Discussion:}

At Ashti lake, both insect species diversity and population density were found to be high as water is productive and nutrient rich
(Bath, 1996; Gyllstrom and Hansson, 2004; Chavan and Lonkar, 2012; Sharma et. al., 2007; Paul and Nandi, 2003). In total 16 insect genera were encountered from January 2010 to December 2012, (Table 1). These belonged to the orders odonata(nymphs), coleoptera (adults only), Diptera (lavae, pupae and adults), Ephemeroptera (larvae only), Neuroptera (larvae only), Trichoptera (larvae) and Hymenoptera (adults).

The order odonata was represented by nymphs of dragonflies and damselflies. The genera observed were Aeshna sp. and Anax sp. These were encountered during the period of April to July. The order coleoptera was represented by beetles belonging to the families Dytiscidae and Hydrophilidae. The genera belonging to this order were Dytiscus and Hydrophilus. The beetles were found throughout the year; however population density was more during May to June and August to October.

Order Diptera was represented by larvae and adults of 5 genera. These were larva and adults culex sp., Chirononemus sp., Anopheles sp., Tabanus sp. And Anthroix sp. Larvi of Culex sp. And chironomous sp. were abundant during January, March, June, and August to November.

Ephemeroptera and Neuroptera were represented by nymphs belonging to 2 genera. The ephemeropteran larvae (Ephemerella $\mathrm{sp}$ ) were found under the stones and gravels during the colder months of January, February, November, And December. Neurepteran larvae (Corydalus sp) were encountered only during the month of June and July.

Order Trichoptera was represented by larvae of 2 genera Leptocercus and ceraclea sp. These were found in the benthic samples during 
the months of January, March, November, and December.

Only one adult species of Hymenoptera was encountered at Ashti lake. It was polynemanatance which was found in the month of February and October.

The available data reveal that at Ashti lake, the population density of insects remained higher during the period extending from May to October, the maximum being in June. During the periods of heavy rains (July and August), the population density declined.Benthic population, consisting mainly of encased trichopteran larvae, was however, more in the months of
January and November.Abundance of insects during the summer period was also observed by Munawar(1970), Das(1979), Rai and Datta(1970), and Kaushik et.al.(1991). According to Elliot (1967) and Hynes(1970), temperature is the most aparent factor affecting the seasonal cycle of insects. Reduced population density during heavy rains was due to drifting of aquatic insects and there larvae along with strong water current.Similar reasons for low insect population density during rains was given by Kaushik et.al.(1991).

Table 1. Auatic insect fauna of Ashti lake (2010 to 2012)

\section{S.NO Order Identified genera / species.}

1. Odonata Nymphs of Aeshnaspand Anaxsp

2. Coleoptera Adults of Dytiscus $\mathrm{sp}$ and Hydrophilus $\mathrm{sp}$

3. Hemiptera Adults of Deronectes $\mathrm{sp}$ and Hydrometra sp.

4. Diptera Lervae and adults of chironomoussp., Anopheles sp.Tabanus sp., culex sp. And Anthorix.sp

5. Ephemeroptera Lervae of Ephemerella sp.

6. Neuroptera Lervae of corydalus sp.

7. Trichoptera Lervae of Leptocerus sp. And ceraclea sp.

8. Hymenoptera Adult of Polynema natans.

\section{References}

Bath, K.S. 1996: Limnological studies on the Harike wertland ecosystem. Ph.D. thesis, Punjabi University, Patiala..

Choudhary S.K.1984 Studies on bio-ecooogy of aquatic insects in Sind and Lidder Streams of Kashmir. Ind. J. Ecol. 11(1): 160-265.

Chavan, R.N. and Lonkar, A.N. 2012: Study and analysis of benthic macro invertebrates of Ramsagar lake, Armori. Di-Gadachiroli(MS) India. Bionano frontier, Global change: impact on biodiversity, culture and technology: volume 5(2-I)p. 107-111.

Das, S. M. 1979: Water Management in the highlands of India. Environ. Managt. 3(5): 385386.

Elliot, J. M. 1967: The life histories and drifting of the Plecoftera and Ephemeroptera in Dartmoor stream. J.Anim. Ecol. 36: 343-361.

Gyllstrom, M. and Hansson, L.A. 2004: Dormancy in fresh water zooplankton : Induction, termination and importance of benthic-Pelagic coupling. Aqua. Sci.66(1): 274295.

Hynes, H. B. N. 1970: The ecology of running waters. Toronto university press, Toronto. P555

Kaushik, B., Sharma, S. and Saxena, D. N. 1991: Ecological studies of certain polluted lentic waters of Gwalior region with reference to aquatic insects communities. In: Current trends in Limnology -1. Ed: Shastree N K. p.185-200.

Mellanby, H. 1963 :Animal life in fresh water. Sixth Ed. Chapman of Hall Ltd., London.

Munawar, M. 1970: Limnological studies on fresh water ponds of Hyderabad.-1. Biotype. Hydrobiologia, 35:137-162

Paul, S. and Nandi, N.C. 2003: Studies on intertidle macro-zoobenthos of Hugli river in and around Calcutta in relation to water and soil conditions. Zoological survey of India. Occasional paper No. 213.2and 136.

Pennak, R.W. 1978: Fresh water invertibrates of the US IInd ed. John Wiley and Sons Inc. New York.

Sharma, K.K., Nitash Sawhney and Subjeet Kour, 2007: Some limnological investigation in Ban Ganga stream, Katara, Jammu and Kashmir state. J. Aqua. Biol.22(2):105-109.

Tonati, G.T. 1980: Fresh water animals of India. An ecological approach. Oxford and IBH Publishing Co. New Delhi.

Ward, H.B. and Whipple, G.C. 1959: Fresh water Biology.Ed.: Edmondson, W.T. IInd ed. John Wiley and Sons Inc. New York, London.

Williams, D.D. and Feltmate, b.W. 1992: Aquatic insects. CAB International Publ. Oxon.U.K.p.358. 